Jurnal Edukasi, Volume 1 Nomor 1, November 2020

\title{
EFEKTIVITAS KULIAH DARING DI TENGAH PANDEMIK
}

THE EFFECTIVENESS OF ONLINE LECTURES IN THE MIDDLE OF

PANDEMIC

Hikma Rasyida

S1 Program Studi Psikologi, Fakultas Kedokteran, Universitas Lambung Mangkurat

Jl.A.Yani km 36 Banjarbaru Kalimantan Selatan Kode Pos 70714, Indonesia

Email:2010914120024@mhs.ulm.ac.id

No. Handpone : 081257953773

\begin{abstract}
ABSTRAK
Persoalan pandemik yang dihadapi dunia membawa kita pada era baru. Segala hal diupayakan untuk memutus mata rantai penularan Covid-19. Salah satunya dalam aspek pendidikan, terdapat perubahan metode pembelajaran menjadi daring. Tujuan penelitian ini adalah untuk mengetahui efektivitas kuliah daring di tengah pandemik. Metode yang digunakan dalam penulisan ini ialah kajian literatur, khususnya menyorot jurnal dan buku dari dosen Universitas Lambung Mangkurat. Hasil penelitian menunjukan bahwa ada mahasiswa yang setuju dengan metode kuliah daring, namun ada juga yang kurang setuju. Ditemukan aspek-aspek yang menjadi masalah utama pada kuliah daring yaitu kurangnya penguasaan teknologi, jaringan yang tidak stabil, pengeluaran biaya yang lebih besar, dan timbulnya masalah psikologis seperti stres.
\end{abstract}

Kata kunci: pandemik, kuliah daring, mahasiswa

\begin{abstract}
ABSTRACK
The pandemic problem that is in the world brings us to a new era. Everything is strived to break the chain of transmission of Covid-19. One of them is in the aspect of education, there is a change in learning methods to be brave. The purpose of this study was to see the effectiveness of lectures in the midst of a pandemic. The method used in this study is literature review, highlighting journals and books from Lambung Mangkurat University lecturers. The results showed that there were students who agreed with the lecture method, but there were also those who disagreed. It was found that there were aspects that became the main problems in a bold lecture, the least was mastery of technology, unstable networks, higher expenses, and the emergence of psychological problems such as stress.
\end{abstract}

Keywords: pandemic, online lecture, college student 


\section{PENDAHULUAN}

Permasalahan yang menjadi topik utama dunia pada tahun 2020 adalah Covid-19. Penyebaran virus tersebut menimbulkan era baru di dunia. Semua aktivitas di berbagai sektor menjadi terganggu. Segala hal diupayakan untuk memutus mata rantai penularan. Dilakukan Physical distancing sebagai cara untuk menghentikan penyebaran Covid-19. Tentunya hal ini berdampak pada bidang pendidikan yang mengalami perubahan metode dalam pembelajaran. Sebagai upaya untuk menghentikan penyebaran virus mematikan ini, pemerintah menerapkan aturan pembelajaran secara daring. Jadi semua pelajar dapat melakukan proses pembelajaran tanpa bertatap muka langsung.

Teknologi harus dimanfaatkan sebaik mungkin agar proses pembelajaran dapat dilakukan secara efektif di masa pendemi ini. Basori (2013 dalam Daheri, Juliana, Deriwanto, \& Amda, 2020) menyatakan bahwa telah tersedia berbagai media yang digunakan sebagai wadah untuk kegiatan pembelajaran secara online atau disebut dengan platform microbloging seperti Google Clasroom, Rumah Belajar, Edmodo, Ruang Guru, Zenius, Google Suite for Education, Microsoft Office 365 for Education, Sekolahmu, Kelas Pintar, dan lain sebagainya.

Mahasiswa dan dosen dituntut harus bisa beradaptasi dengan metode pembelajaran yang baru ini. Tentulah tidak semua orang bisa menyesuaikan diri dengan hal ini. Faktanya masih ada mahasiswa yang bingung menggunakan teknologi dalam proses pembelajaran. Bahkan ada beberapa dosen yang merasa sulit menggunakan metode baru ini dalam menyampaikan materi. Rasanya intensitas interaksi antar dosen dan mahasiswa menjadi menurun dari biasanya. Dosen juga kesulitan melihat tingkat pemahaman mahasiswa saat proses pembelajaran berlangsung. Ditambah lagi dengan kendala jaringan dan pengeluaran paket internet yang lebih banyak dari biasanya membuat perkuliahan daring menjadi semakin sulit untuk dilakukan, namun harus tetap dijalankan.

Selain itu, pada masa pandemik ini hubungan sosial harus dilakukan secara tidak langsung. Dapat dilihat interaksi yang ada, baik antar mahasiswa dengan mahasiswa lain maupun dengan dosennya menjadi tidak optimal karena hanya terbatas pada hubungan secara virtual dan tidak dapat berinteraksi di kehidupan nyata. Padahal Aridarmaputri, Akbar , \& Yunairrahmah (2016) menyatakan bahwa interaksi sosial adalah hubungan sosial yang bersifat dinamis antara individu dengan individu lain, individu dengan kelompok, atau kelompok dengan kelompok lain yang dibutuhkan oleh manusia. Namun sayangnya kebutuhan ini tidak dapat dilakukan dengan normal seperti biasanya. Faktanya nilai sosial akan mudah didapat dalam kehidupan nyata dibanding hubungan yang dilakukan melalui teknologi digital. Seperti halnya dalam kegiatan pembelajaran yang banyak dikeluhkan oleh mahasiswa sebab ditemukan banyak permasalahan selama mengikuti kelas online yang mengganggu kegiatan pembelajaran menjadi tidak optimal. Namun, tidak ada pilihan lain untuk menjalankan proses pembelajaran selain via online karena situasi yang tidak memungkinkan untuk melakukan pembelajaran yang normal yaitu secara offline atau bertatap muka langsung. 


\section{METODE}

Penulisan artikel ini menggunakan metode kajian literatur dengan mengambil referensi dari beberapa jurnal dan sumber pustaka. Tepatnya ada 12 jurnal termasuk sumber pustaka mengenai efektifitas kuliah daring di tengah pandemik yang ditelaah. Khususnya penulisan artikel ini banyak menyorot jurnal dan buku dari dosen Universitas Lambung Mangkurat yang diteliti, dipahami dan diambil beberapa datanya untuk dibahas dan ditarik kesimpulan.

\section{HASIL DAN PEMBAHASAN}

Menurut undang-undang nomor 20 Tahun 2003 pembelajaran merupakan proses interaksi antara peserta didik dan pendidik dengan sumber belajar pada lingkungan belajar (Pohan, 2020). Pembelajaran dilakukan guna memperoleh ilmu pengetahuan. Kegiatan pembelajaran sudah umum dilakukan, apalagi bagi mahasiswa yang merupakan suatu kewajiban yang harus dipenuhi. Namun, akhir-akhir ini metode pembelajaran yang dilakukan berbeda dengan sebelumnya. Pandemik mengubah banyak aspek di kehidupan manusia pada era ini sehingga disebutlah new normal. Segalanya menjadi baru, maksudnya sistem atau kebiasaan yang ada di masyarakat banyak yang berubah karena tuntutan dari pemerintah yang menerapkan banyak aturan baru guna menghentikan penyebaran Covid-19. Beberapa aturan yang harus ditaati oleh masyarakat adalah memakai masker, menggunakan hand sanitizer, mencuci tangan, menjauhi keramaian, dan melakukan social distancing.

Aturan social distancing dan menjauhi keramaian jelas membuat bidang pendidikan harus mengubah kelas tatap muka langsung menjadi kelas tatap muka tidak langsung. Caranya dengan memanfaatkan teknologi untuk proses interaksi antara pengajar dan pelajar. Kegiatan pembelajaran ini disebut dengan pembelajaran daring. Meidawati, dkk (dalam Pohan, 2020) menerangkan bahwa pembelajaran Daring Learning merupakan pendidikan formal yang diselenggarakan suatu instansi pendidikan dengan tujuan menghubungkan peserta didik dengan instrukturnya dan berbagai sumber daya yang terkait dalam kegiatan pembelajaran meskipun terpisah jarak namun bisa berinteraksi menggunakan sistem telekomunikasi interaktif.

Dengan tersedianya banyak wadah atau media dalam pembelajaran daring membuat kegiatan ini menjadi mudah dilakukan. Namun, masalahnya ada pada subjek atau orang yang memanfaatkan perkembangan teknologi ini. Masalah utama pembelajaran secara online ditemukan pada kurangnya penguasaan teknologi, jaringan yang tidak stabil, pengeluaran biaya yang lebih besar, dan timbulnya masalah psikologis seperti stres. Dalam ruang lingkup kuliah, semua mahasiswa sudah memiliki alat penunjang yang dapat dikatakan wajib dimiliki seperti smartphone dan laptop atau notebook.

Akan tetapi banyak mahasiswa khususnya yang baru memasuki dunia perkuliahan masih merasa asing dengan penggunaannya. Sedangkan pada situasi saat ini tidak ada cara lain selain melangsungkan kegiatan perkuliahan secara daring. Jadi mau tidak mau mahasiswa harus bisa beradaptasi dengan pemanfaatan teknologi dalam kegiatan pembelajaran jika ingin mengikuti dan 
melanjutkan pendidikannya. Bukan hanya mahasiswa, ternyata ada dosen yang merasa kesulitan dengan metode pembelajaran yang baru ini, khususnya dosen senior. Saat kegiatan perkuliahan berlangsung beliau nampak bingung menggunakan media pembelajaran online yang ada dan meminta bantuan orang lain yang lebih mengerti teknologi.

Hal ini jelas membuat kegiatan perkuliahan menjadi tidak efektif. Belum lagi gangguan jaringan yang tidak stabil. Ini biasa dirasakan oleh mahasiswa yang tinggal jauh dari kota atau tinggal di tempat terpencil yang sulit menemukan koneksi internet yang bagus. Saat kegiatan perkuliahan dimulai rasanya niat untuk belajar sudah terkumpul namun akhirnya mood menurun akibat jaringan yang tidak mendukung. Alhasil mahasiswa menjadi malas dan tidak bersemangat lagi memerhatikan penjelasan dosen sebab sudah ketinggalan materi. Bukan hanya mahasiswa yang bisa mengalami gangguan jaringan, faktanya dapat juga ditemui dosen yang memiliki koneksi internet tidak bagus yang membuat penyampaian materi menjadi tidak jelas dan membuat mahasiswa tidak paham. Ditambah lagi waktu menjadi tidak efisien dan terbuang sia-sia saat menunggu koneksi stabil.

Masalah yang tak kalah penting ialah berhubungan dengan finansial. Tidak semua mahasiswa memiliki akses wifi di rumahnya masing-masing. Nyatanya banyak mahasiswa yang mengeluhkan pengeluaran dana yang banyak dalam membeli paket internet guna mengikuti kuliah online. Ini menjadi beban tersendiri untuk mahasiswa khususnya yang kurang mampu. Pemberian subsidi kuota internet yang tak kunjung datang membuat mereka terpaksa mengeluarkan uang lebih untuk membeli paket internet. Akhirnya mahasiswa pun mudah merasa stres. Hendaknya pihak yang bersangkutan dengan pemberian subsidi kuota internet dapat membagikannya secepat mungkin pada seluruh mahasiswa, khususnya yang kurang mampu agar permalasahan pengeluaran biaya berlebih ini dapat teratasi.

Permasalahan lainnya ialah banyaknya tugas yang diberilan oleh dosen, namun mereka tidak mengerti dengan apa yang dipelajari dan bagaimana menyelesaikan tugas tersebut. Alhasil mahasiswa pun akan merasa stres dan pesimis. Dibutuhkan rasa percaya diri yang tertanam pada mahasiswa. Kepercayaan diri merupakan bentuk keyakinan terhadap kemampuan yang dimiliki untuk menampilkan sebuah perilaku dalam mencapai suatu tujuan (Saputri, Lestari, \& Zwagery, 2020). Efikasi diri atau rasa percaya diri atau keyakinan mahasiswa mengenai kemampuannya menyelesaikan tugas terbilang rendah. Afnan, Fauzia, \& Tanau (2020) menyatakan bahwa efikasi diri dan rasa stres memiliki hubungan variabel yang negatif. Artinya, semakin tinggi efikasi diri mahasiswa maka semakian rendah tingkat stresnya. Sebaliknya, semakin rendah efikasi diri maka semakin tinggi tingkat stresnya.

Biasanya hubungan sosial seperti interaksi, berbicara, berbagi mengenai masalah yang dipikirkan, dan bersenda gurau dengan teman dapat mengurangi stres mahasiswa. Namun, mereka tidak dapat melakukannya pada masa pandemik. Tidak memungkinkan untuk mereka bertemu langsung. Sebenarnya mereka bisa saja berinteraksi menggunakan 
perkembangan teknologi komunikasi. Akan tetapi rasanya tetap tidak sama dengan bertemu di dunia nyata. Interaksi yang ada terbatas pada komunikasi jarak jauh yang dilakukan di dunia maya.

Akan tetapi, ada juga mahasiswa yang mengalami berbagai macam kesulitan dalam mengikuti kegiatan kuliah daring namun ia tidak mengeluh. Abbas \& Erlyani (2020) menyatakan bahwa manusia dilahirkan dalam bingkai tabularasa dan kemudian berkembang dalam lingkungan sosial yang menentukan dan membentuk jati dirinya, dalam hal ini pola pikir atau mindset yang menabalkan, raupan informasi penting. Bila seseorang terlahir dari keluarga pengeluh berarti ia dikelilingi lingkungan yang kurang baik maka besar kemungkinan orang tersebut menjadi pengeluh. Namun bisa juga berlaku sebaliknya, yaitu seseorang yang tumbuh di keluarga yang selalu berusaha dan pantang menyerah walaupun ada masalah maka besar kemungkinan orang tersebut menjadi pribadi yang tidak gampang mengeluh dan terus bersemangat. Jadi kembali lagi ke pribadi mahasiswa itu sendiri. Bagaimana sikap ia menghadapi masalah sangatlah menentukan hasil akhir. Oleh karena itu penting membentuk karakter diri menjadi lebih berkualitas dan pantang menyerah menghadapi permasalahan termasuk adaptasi terhadap kegiatan kuliah secara daring di tengah pandemik.

Efektifitas kuliah secara daring ini dapat dilihat dari kacamata lain. Maksudnya, ada beberapa mahasiswa yang tidak merasa terbebani dengan metode baru ini. Mereka meresa kuliah online jauh lebih menyenangkan dibanding kuliah offline karena mereka tidak perlu membuang tenaga untuk pergi ke kampus. Apalagi untuk mahasiswa yang tempat tinggal asalnya jauh dari lokasi kampus. Mereka dapat diam di rumah dan berkumpul dengan keluarga. Jadi mereka dapat dekat dengan orang tua tapi pendidikan tetap jalan. Namun ini hanya dirasakan oleh mahasiswa yang di tempatnya tersedia akses wifi atau memiliki finansial yang cukup untuk membeli paket internet dan di tempatnya kualitas jaringan bagus. Seandainya jaringan di tempat tinggalnya kurang mendukung maka bisa dipastikan mereka akan kesulitan juga.

Mereka yang menguasai teknologi juga mudah beradaptasi. Rasanya tidak ada masalah mengenai pembelajaran daring yang diterapkan karena mereka sudah terbiasa menggunakan teknologi. Selain itu, bagi mahasiswa yang mengamati penjelasan dosen dari awal hingga akhir pastilah bisa menangkap materi baik banyak maupun sedikit. Untuk urusan paham 100\% bisa dipikirkan belakangan. Yang paling penting adalah memusatkan perhatian pada materi yang disampaikan, bertanya jika ada yang kurang dimengerti, dan mengulang materi pembelajaran di waktu senggang. Salah satu keuntungan kuliah online ialah kegiatan pembelajarannya dapat direkam sehingga penjelasan dosen bisa diulang kembali di waktu lain.

\section{Dalam mengikuti kegiatan} perkuliahan khususnya di tengah pandemik saat ini, penting untuk mengatur diri agar tidak stres. Abbas (2020) menerangkan bahwa memanage psikologis itu hal yang harus dilakukan oleh diri sendiri sebab yang mempunyai pikiran dan perasaan adalah diri sendiri bukan orang lain. Bagi 
mahasiswa yang bisa mengubah pemikiran negatif menjadi pemikiran positif pastilah bisa mengendalikan perasaannya menjadi lebih tenang dan tidak stres. Mahasiswa harus bisa melihat peluang disetiap kejadian. Jangan biarkan sikap pesimis dan pikiran negatif terus menghantui diri. Cobalah untuk percaya dengan kekuatan yang dimiliki. Jika menemukan kesulitan maka jangan langsung menyerah dan ingin berhenti. Jika melakukan kesalahan di awal maka janganlah menutup diri dan tak ingin mencoba lagi. Belajar itu memang sulit. Apalagi beradaptasi dari tahap siswa menjadi mahasiswa. Wajar jika menemui kesulitan, apalagi pada masa pandemik yang mengantarkan mahasiswa merasakan manis pahit kuliah daring.

Selain itu rasa syukur harus ditanamkan dalam diri mahasiswa. Seligman (2002 dalam Helmiyyah, Erlyani, \& Mayangsari, 2019) menyatakan bahwa rasa syukur merupakan bentuk emosi positif pada diri seseorang dalam mengekspresikan kebahagiaan dan rasa terimakasihnya terhadap segala kebaikan yang dialaminya. Mahasiswa harus bersyukur bisa tetap kuliah di masa pandemik saat ini. Untunglah dapat ditemukan solusi untuk bisa belajar tanpa khawatir penyebaran Covid-19 akan bertambah. Disetiap kesulitan pasti ada kemudahan. Mengendalikan diri berpikir positif dan terus bersyukur adalah kuncinya.

Sikap yang wajib dimiliki Mahasiswa adalah kritis, bertanggung jawab, dewasa, mandiri, memiliki prestasi yang baik dan dapat menyelesaikan tugastugasnya dengan baik, dimana tujuan diberikannya tugas-tugas tersebut adalah untuk mengukur kompetensi atau kemampuan mahasiswa dalam bidang akademik (Putri, Mayangsari, \& Rusli (2020). Motivasi belajar yang ada pada diri mahasiswa harus ditingkatkan. Meskipun kuliah dilakukan secara daring, diharapkan tidak mengurangi rasa semangat mahasiswa dalam menuntut ilmu. Motivasi berprestasi merupakan bagian penting yang menjadi faktor pendorong individu dalam mencapai keberhasilan (Sitanggang, Mayangsari, \& Zwagery, 2020). Chu dan Choi (2005 dalam Rachmah, Mayangsari, \& Akbar, 2015) menerangkan bahwa motivasi merupakan kekuatan yang mendorong seseorang melakukan suatu hal, baik dorongan dari dalam diri yang disebut motivasi instrinsik, maupun dorongan yang dihasilkan dari salah satu baik positif atau negatif kemungkinan yang asalnya dari luar individu yang disebut motivasi ekstrinsik. Kemauan besar yang dimiliki individu dapat mempengaruhi motivasi yang ada. Selain itu, Essyani (2010 dalam Mayangsari, 2016) menyatakan bahwa hal yang sangat mempengaruhi motivasi berprestasi seorang anak adalah lingkungan keluarga, khususnya peran orang tua yang memiliki hubungan intens dengan anak sehingga memberikan kontribusi besar terhadap perkembangan anak.

\section{KESIMPULAN}

Di tengah pandemik yang melanda dunia, kita harus bisa beradaptasi dengan era baru. Dalam aspek pendidikan, pembelajaran diselenggarakan secara daring agar kegiatan pembelajaran tetap bisa dilakukan meski jarak jauh memisahkan. Pendapat mahasiswa mengenai efektivitas metode pembelajaran ini berbeda-beda. Ada yang merasa kesulitan beradaptasi dengan kuliah daring 
dan ada juga yang tidak keberatan dengan metode baru ini.

Masalah utama kuliah daring ditemukan pada kurangnya penguasaan teknologi, jaringan yang tidak stabil, pengeluaran biaya yang lebih besar, dan timbulnya masalah psikologis seperti stres. Penting untuk ditanamkan rasa semangat, percaya diri, motivasi diri dan sikap pantang menyerah pada mahasiswa dalam menghadapi permasalahan. Belajar beradaptasi dalam penggunaan teknologi dan mengupayakan untuk memahami materi yang disampaikan dosen adalah tugas mahasiswa. Untuk masalah jaringan yang tidak stabil, mahasiswa bisa melihat rekaman ulang kegiatan perkuliahan saat jaringan sudah mulai membaik. Untuk masalah banyaknya pengeluaran paket internet dalam kuliah daring dapat diatasi jika mahasiswa menerima subsidi kuota internet dari pihak yang bersangkutan dalam bidang tersebut.

Pendidikan harus tetap jalan dalam kondisi pandemik karena teknologi dapat dimanfaatkan sebagai media pembelajaran. Sayang apabila kita tidak menggunakan ketersediaan yang ada. Efektivitas kuliah daring akan semakin optimal apabila masalah-masalah utama bisa diatasi. Menurut saya, kegiatan kuliah daring merupakan kebijakan tepat yang dilakukan pada masa pandemik. Tidak mungkin dosen dan mahasiswa melakukan kuliah tatap muka langsung karena dikhawatirkan akan menambah penularan Covid-19.

\section{DAFTAR PUSTAKA}

Abbas, E. W., \& Erlyani, N. (2020). Menulis di Kala Badai Covid-19.

Afnan, A., Fauzia, R., \& Tanau, M. U. (2020). HUBUNGAN EFIKASI DIRI DENGAN
STRESS PADA MAHASISWA YANG BERADA DALAM FASE QUARTER LIFE CRISIS. Jurnal Kognisia: Jurnal Mahasiswa Psikologi Online, 3(1), 2329.

Aridarmaputri, G. S., Akbar, S. N., \& Yuniarrahmah, E. (2016). Pengaruh jejaring sosial terhadap kebutuhan afiliasi remaja di program Studi Psikologi Fakultas Kedokteran Universitas Lambung Mangkurat. Jurnal Ecopsy, 3(1).

Daheri, M., Juliana, J., Deriwanto, D., \& Amda, A. D. (2020). Efektifitas whatsapp sebagai media belajar daring. Jurnal Basicedu, 4(4), 775-783.

Helmiyyah, S., Erlyani, N., \& Mayangsari, M. D. (2020). HUBUNGAN RASA SYUKUR DENGAN ALTRUISME PADA MASYARAKAT YANG TINGGAL DI WILAYAH TAMBANG BATUBARA ASAM-ASAM. Kognisia prodi Psikologi FK ULM, 2(2), 140-148.

Mayangsari, M. D. (2016). Motivasi Berprestasi Mahasiswa Ditinjau dari Penerimaan Ecopsy, 1(1).

Pohan, A. E. (2020). Konsep Pembelajaran Daring Berbasis Pendekatan IImiah. Penerbit CV. SARNU UNTUNG.

Putri, C. P., Mayangsari, M. D., \& Rusli, R. (2020). PENGARUH STRES AKADEMIK TERHADAP ACADEMIC HELP SEEKING PADA MAHASISWA PSIKOLOGI UNLAM DENGAN INDEKS PRESTASI KUMULATIF RENDAH. Kognisia prodi Psikologi FK ULM, 1(2), 28-37.

Rachmah, D. N., Mayangsari, M. D., \& Akbar, S. N. (2015). Motivasi belajar sebagai mediator hubungan kecerdasan adversitas dan prokrastinasi akademik pada mahasiswa yang aktif berorganisasi. Jurnal Cakrawala Pendidikan, 34(2). 
8 Jurnal Edukasi, Volume 1 Nomor 1, November 2020

Saputri, L. K., Lestari, D. R., \& Zwagery, R. V. (2020). Hubungan Pola Asuh Orang Tua dengan Kepercayaan Diri Remaja di SMK Borneo Lestari Banjarbaru. Dunia Keperawatan: Jurnal Keperawatan dan Kesehatan, 8(1), 34-42.

Sitanggang, N. G., Mayangsari, M. D., \& Zwagery, R. V. (2020). HUBUNGAN ANTARA PENETAPAN TUJUAN DENGAN MOTIVASI BERPRESTASI PADA SISWA SMK NEGERI 1 MARTAPURA. Kognisia prodi Psikologi FK ULM, 1(1), 17-22.

WARMANSYAH ABBAS, E. R. S. I. S. (2020). Menulis di Era Covid-19: Memanage Trauma Psikologis Menghindari Psikosomatis. Menulis di Era Covid-19: Memanage Trauma Psikologis Menghindari Psikosomatis. 